\title{
PENENTUAN KANDUNGAN PIGMEN KLOROFIL PADA LAMUN JENIS Halophila ovalis DI PERAIRAN MALALAYANG
}

\section{(Determination of Chloropil Pigment Content on Halophila ovalis Seagress in Malalayang Waters)}

\author{
Christy I. Rosang $^{1 *}$, Billy Th. Wagey ${ }^{1}$ \\ 1. Program Studi IImu Kelautan, Fakultas Perikanan dan IImu Kelautan, Universitas Sam \\ Ratulangi, Manado \\ *e-mail :christyrosang@gmail.com
}

\begin{abstract}
The world's plants are diverse. Some are on land and in the sea. Seagrass Halophila ovalis is an oval-shaped marine plants and live on sandy substrate and muddy sand. This seagrass contains pigment that can be seen from the results of the spectrophotometer analysis on total pigment extracts and its separation test through Thin Layer Chromatography (TLC). In the extraction process we used acetone and petroleum ether as separators solution. Based on spectrophotometry curve there were two peaks at the wavelength of $428 \mathrm{~nm}$ and $660 \mathrm{~nm}$ were visible and it revealed a mixture of pigments, as well. After pigments separation with TLC, there were three layers, first layer identified as yellow carotenoid pigments with Rf value of 0.93 , the second layer was green, identified as chlorophyll and with Rf of 0.96 and the third layer was gray and it was identified as feofitin in a value of $\mathrm{Rf} 0.97$.
\end{abstract}

Keywords: Halophila ovalis, Pigment, Chlorophil, Thin Layer Chromatograpy

Tumbuhan di dunia beraneka ragam. Ada yang di darat dan ada yang di laut. Lamun Halophila ovalis merupakan tumbuhan laut yang berbentuk oval dan hidup pada substrat berpasir dan pasir bercampur lumpur. Lamun ini mengandung pigmen terlihat pada hasil analisis spektrofotometer pada ekstrak pigmen total lamun dan pemisahan pigmen lewat uji Kromatografi Lapis Tipis (KLT). Dalam proses ekstraksi digunakan pelarut aseton untuk penggerusan dan petroleum eter sebagai pemisah larutan. Pada kurva spektrofotometer terlihat dua puncak yaitu pada panjang gelombang $428 \mathrm{~nm}$ dan $660 \mathrm{~nm}$ terlihat masih adanya pencampuran pigmen. Berdasarkan hal tersebut maka dilakukan pemisahan pigmen lewat KLT dan terdapat tiga lapisan yaitu lapisan pertama berwarna kuning teridentifikasi adalah pigmen karotenoid dengan nilai Rf 0,93 , lapisan kedua berwarna hijau adalah klorofil a dengan nilai rata-rata $\mathrm{Rf} 0,96$ dan lapisan ketiga berwarna kelabu yang teridentifikasi adalah feofitin a dengan nilai $\operatorname{Rf} 0,97$.

Kata kunci: Halophila ovalis, Pigmen, Klorofil, Kromatografi Lapis Tipis

\section{PENDAHULUAN}

Lamun merupakan satu-satunya tumbuhan laut berbunga yang hidup secara tetap di lingkungan perairan pantai yang dangkal dan merupakan kunci dalam peranan ekologis (Calumpong and Menez, 1997)). Selain berbunga, lamun juga memiliki biji dan menghasilkan buah. Lamun juga mempunyai akar dan sistem internal untuk mengangkut gas dan zatzat hara. Halophila ovalis merupakan salah satu jenis tumbuhan lamun yang diduga memiliki sejumlah pigmen yang mungkin bermanfaat.

Tujuan dari penelitian ini yaitu mengetahui kandungan pigmen klorofil yang terdapat pada tumbuhan lamun jenis $H$. ovalis dengan menggunakan teknik Kromatografi Lapis Tipis (KLT). 


\section{METODE PENELITIAN}

\section{Tempat dan Waktu}

Pengambilan sampel dilaksanakan pada bulan Agustus di Perairan Malalayang, Kota Manado. Sedangkan kegitan ekstraksi dilakukan di Laboratorium Biomolekuler dan Farmasitika Laut FPIK UNSRAT. Analisis spektrofotometer dilakukan di Laboratorium Analisis Farmasi FMIPA UNSRAT.

\section{Metode Pengambilan Data}

Pengambilan sampel dilakukan dengan menyelam pada kedalaman 2-5 meter, kemudian mencabut sampel langsung dari substratnya. Setelah diambil selanjutnya dicuci dengan air laut kemudian dibungkus dengan aluminum foil dan dimasukkan ke dalam kotak pendingin dan dibawa ke laboratorium untuk penelitian lebih lanjut.

\section{Proses Ekstraksi Klorofil}

Dalam proses ekstraksi, sampel masing-masing ditimbang sebanyak 3 gr dengan menggunakan timbangan analitik. Sampel hasil penimbangan kemudian digerus dalam aseton sampai pigmen pada sampel terlarut dalam aseton kemudian disaring dengan menggunakan kertas saring dalam labu pemisah. Hasil ekstrak kemudian ditambahkan larutan petroleum eter (PE) sebanyak $5 \mathrm{ml}$ dan aquades sebanyak $15 \mathrm{ml}$ maka akan terbentuk dua lapisan. Lapisan bawah dibuang dan lapisan atas diambil sebagai hasil ekstrak pigmen total dalam PE.

Hasil ekstrak dimasukkan ke dalam tabung reaksi secara terpisah. Selanjutnya hasil ekstrak dianalisis spektrofotometer untuk penentuan nilai standar konsentrasi pigmen.

\section{Analisis Jenis Pigmen}

Berikut ini merupakan langkahlangkah dalam menentukan jenis pigmen dengan menggunakan Kromatografi Lapis Tipis :
1. Penyediaan pelat silika gel sebagai fase tetap.

2. Pembuatan Kromatogram, bagian bawah dan bagian atas pelat dibuat garis horizontal dengan jarak $1 \mathrm{~cm}$ dari ujung bawah dan $1 \mathrm{~cm}$ dari ujung atas. Pada garis awal dibuat spot dan ditotolkan larutan pigmen yang akan dianalisis menggunakan pipet kapiler.

3. Pelat kemudian dimasukkan ke dalam bejana yang berisi eluen. Eluen yang digunakan adalah Petroleum Eter : Aseton (80:20) (Mantiri, 1995).

4. Setelah eluen naik sampai batas yang ditetapkan, pelat silika diangkat dari bejana, spot-spot yang terlihat ditentukan nilai Rf.

Penentuan nilai $\mathrm{Rf}$ dilakukan dengan membagi jarak yang ditempuh oleh senyawa dari titik asal dengan jarak yang ditempuh pelarut dari titik asal (Sastrohamidjojo, 1991). berikut:

Perhitungannya adalah sebagai

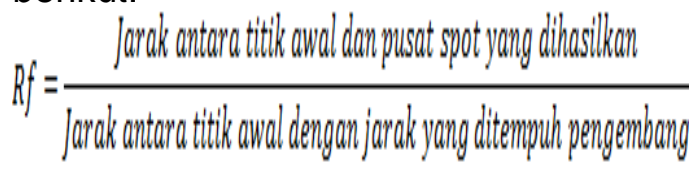

\section{Analisis Data}

Ekstrak pigmen total dalam
petroleum eter diserap dengan spektrofotometer dengan panjang gelombang 380-70 nm. Kurva hasil serapan digunakan untuk menghitung konsentrasi pigmen klorofil.

Nilai konsentrasi klorofil dapat dihitung dengan menggunakan rumus Jeffrey and Humphrey (1975) yaitu :

Klorofil $a=11,85 . \quad E_{664^{-}}$1.54. $E_{647^{-}}$ 0.08. $\mathrm{E}_{630}$

Keterangan :

$$
\begin{aligned}
& \mathrm{E}_{664}=\text { Nilai absorbans pada panjang } \\
& \mathrm{E}_{647}=\text { Nilai absorbans pada panjang } \\
& \text { gelombang } 647 \mathrm{~nm} \\
& \mathrm{E}_{630}=\text { Nilai absorbans pada panjang }
\end{aligned}
$$




\section{HASIL DAN PEMBAHASAN}

\section{Deskripsi Lokasi}

Lokasi pengambilan sampel di Pantai Malalayang berdekatan dengan muara sungai dan kondisi substrat lokasi pengambilan sampel adalah berpasir dan pasir bercampur lumpur. Berdasarkan pengamatan lamun jenis $H$. ovalis cukup banyak ditemukan di daerah tersebut. Kondisi lingkungan berpengaruh terhadap lamun $H$. ovalis, hal ini berdasarkan pendapat Den Hartog (1970), kondisi lingkungan sangat berpengaruh terhadap $H$. ovalis terutama pada daun.

Pada substrat keras, lumpur terbuka dan pasir disepanjang batas pasang surut umumnya daun $H$. ovalis memiliki ukuran kecil. Sedangkan pada habitat yang selalu tergenang umumnya ukuran daun lebih besar.

Secara geografis $H$. ovalis memiliki distribusi luas yaitu di daerah garis pantai tropis dan hangat dari Perairan Indo-Pasifik Barat. Lamun ini mampu hidup sampai pada kedalaman $60 \mathrm{~m}$. Tumbuh pada habitat dengan substrat berpasir dan pasir bercampur lumpur. Seperti yang terlihat pada Gambar $1, H$. ovalis yang ditemukan di perairan Malalayang memiliki bentuk daun bulat telur, daun berpasangan dengan tangkai, tepi daun memiliki sisik, urat daun 10-15 dengan panjang helaian daun 11-40 mm.

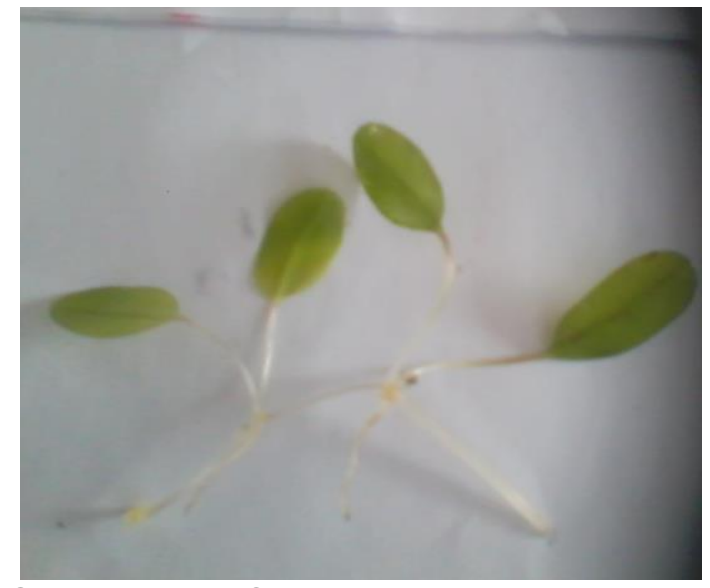

Gambar 1. Sampel lamun $H$. ovalis dari perairan Malalayang

\section{Analisis Jenis Pigmen}

Hasil dari ekstrak pigmen total terlihat adanya dua lapisan yaitu lapisan atas dan lapisan bawah yang kemudian lapisan atas tersebut diambil dan dianalisis dengan spektrofotometer pada panjang gelombang 380-700 nm. Hasil analisis tersebut terlihat kurva Gambar 2 yang membentuk dua puncak yaitu $428 \mathrm{~nm}$ dan $660 \mathrm{~nm}$. Menurut Goodwin (1988), pigmen tersebut adalah pigmen klorofil a. Dari hasil tersebut juga menunjukan masih terjadi pencampuran pigmen. Diasumsikan pigmen jenis karotenoid tercampur diantara pigmen klorofil. Pigmen karotenoid berada pada kisaran 380-550 nm. Pada lamun pigmen $\beta$ - karoten yang mempunyai dua puncak satu lekukan. Berdasarkan hasil tersebut, maka perlu dilakukan pemisahan dengan menggunakan analisis Kromatografi Lapis Tipis.

Pemisahan jenis pigmen menggunakan pengembang petroleum eter (PE) dan aseton dengan perbandingan 80:20. Hasil pemisahan dengan Kromatografi Lapis Tipis

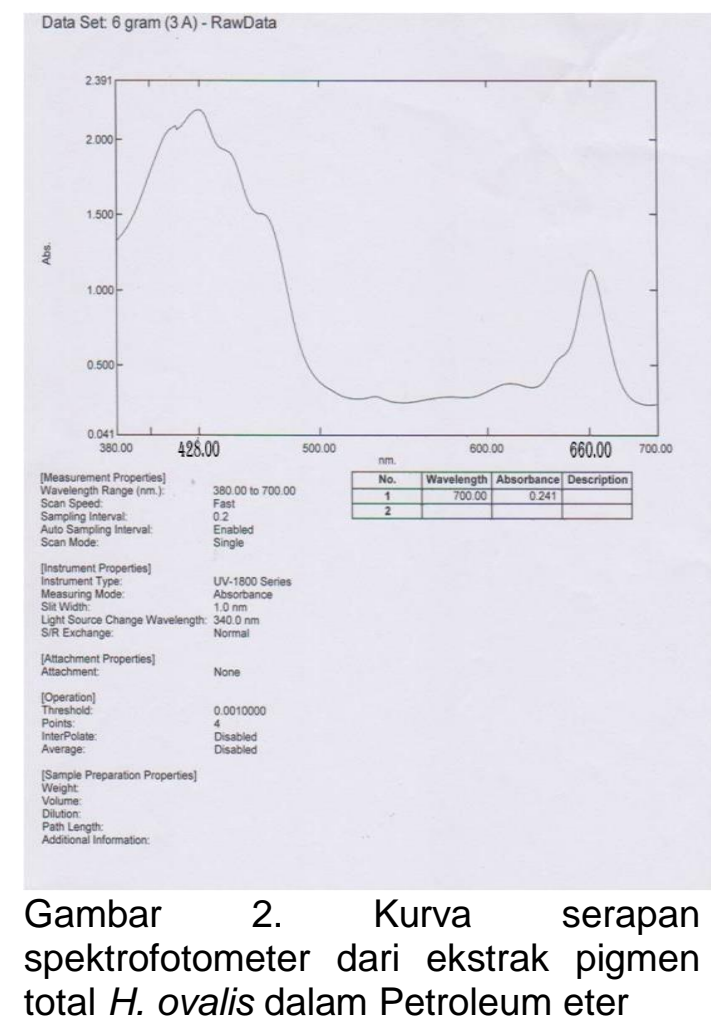


Tabel 1. Hasil analisis KLT dari ekstrak pigmen total lamun $H$. Ovalis
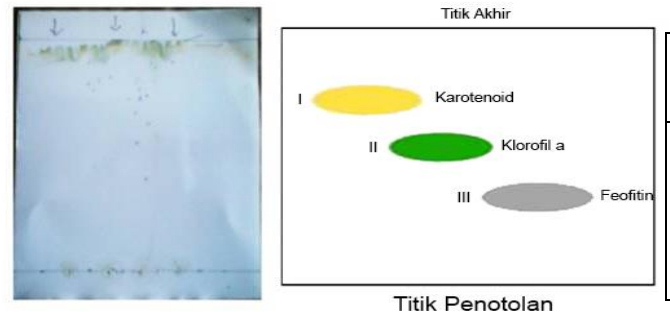

\begin{tabular}{|l|l|l|l|l|}
\hline Eluen & $\begin{array}{c}\text { Lapis } \\
\text { an }\end{array}$ & Rf & Warna & \multicolumn{1}{|c|}{$\begin{array}{c}\text { Jenis } \\
\text { pigmen }\end{array}$} \\
\hline PE $:$ & 1 & 0,93 & Kuning & Karotenoid \\
\cline { 2 - 5 } $\begin{array}{l}\text { Aseton } \\
(80: 20)\end{array}$ & 2 & 0,96 & Hijau & Klorofil a \\
\cline { 2 - 5 } & 3 & 0,97 & Kelabu & Feofitin \\
\hline
\end{tabular}

ekstrak total daun $H$. ovalis terlihat tiga lapisan. Lapisan pertama berwarna kuning dengan nilai $\mathrm{Rf} 0,93$, lapisan kedua berwarna hijau dengan rata-rata Rf 0,96 dan lapisan berwarna kelabu dengannilai Rf 0,97.

Lapisan berwarna kelabu tersebut adalah pigmen feofitin a (Harborn, 1987), merupakan pigmen klorofil bebas atom

magnesium. Sering ditemukan pada proses pemisahan klorofil melalui proses ekstraksi. Proses penggerusan sampel yang terlalu keras dapat menyebabkan terlepasnya atom magnesium dari gugus pirol. Seperti pigmen feofitin pada alga Eucheuma denticulatum hasil dari ekstraksi klorofil juga ditemukan feofitin, pigmen berwarnkelabu (Ande, 2000).

\section{Konsentrasi Pigmen}

Berdasarkan perhitungan

konsentrasi total pigmen klorofil a, diperoleh nilai :

Klorofil $a=11,85$. E664- 1,54. E6470,08 . E630

$=11,85 \cdot 0,503-1,54 \cdot 0,502-0,08 \cdot 0,045$

$=5,96-0,77-0,003$

$=5,187 \mu \mathrm{g} / \mathrm{ml}$

Nilai konsentrasi pigmen klorofil a pada $H$. ovalis sebesar $5,187 \mu \mathrm{g} / \mathrm{ml}$, lebih tinggi jika dibandingkan dengan konsentrasi pada alga $E$. denticulatum.

\section{KESIMPULAN}

Berdasarkan hasil penelitian pada lamun $H$. ovalis dapat ditarik kesimpulan sebagai berikut :

1. Pigmen pada ekstrak total adalah campuran dari pigmen karotenoid dan klorofil

2. Pigmen yang terkandung dalam lamun $H$. ovalis mempunyai dua puncak yaitu $428 \mathrm{~nm}$ dan $660 \mathrm{~nm}$ adalah pigmen klorofil $a$.

3. Jenis-jenis pigmen pada lamun adalah klorofil $a$, feofitin dan karotenoid. Nilai konsentrasi total klorofil pada lamun adalah 5,187 $\mu \mathrm{g} / \mathrm{ml}$.

\section{DAFTAR PUSTAKA}

Ande, M.T. 2000. Kandungan Pigmen Selama Pertumbuhan Alga Merah Eucheuma denticulatum (N.L. Burman) Collins et Hervey Di Perairan Pesisir Pulau Nain. Skripsi. FPIK. Unsrat Manado

Calumpong, H.P., E.G. Menez. 1997. Field Guide to the Common Mangroves, Seagress and Algae of The Philippines.

Den Hartog, C. 1970. The Seagress of the World. North Holland Publishing Company. Amsterdam. 275 hal. 
Goodwin, T.W. 1980. The Biochemistry of the Carotenoids. Publisher in USA. By Chapman. Hall inc.

Harborne, J.B. 1987. Metode Fotokimia, Penuntun Cara Modern Menganalisis Tumbuhan. Institut Teknologi Bandung. Bandung.

Jeffrey, S.W. \& G. F. Humphrey. 1975. New Spectrophotometric equations for determining chlorophylld a, b, c, c1 and c2 in higher plants, algae, and natural phytoplankton. Journal of Biochemistry and Physiology Pflanzen 167:191-194.

Mantiri, D.M.H., Negre Sadargues, N., Castillo, R., Trilles J.P. 1995. Evolution of carotenoid metabolic capabilites during the early development of the Europen lobster Hommarus gammarus (Linne 1758) Comp Biochem. Phyciol. Vol. III.

Sastrohamidjojo, H. $\quad 1991$. Kromatografi. Penerbit Liberty. Yogyakarta 